\title{
Fiduciary Security Registration of Vehicles by Financing Companies According to Finance Ministerial Regulation Number 130/ Pmk.010/2012
}

\author{
Bias Lintang Dialog¹, Haris Budiman, Krisna Monita², Dikha Anugrah ${ }^{3}$, Anthon \\ Fatanudhien ${ }^{4}$ \\ ${ }^{1234}$ Faculty of Law, Universitas Kuningan, Kuningan, Indonesia \\ \{lintangdialog@uniku.ac.id ${ }^{1}$, haris.budiman@uniku.ac.id², krisnamonita21@gmail.com ${ }^{3}$ \}
}

\begin{abstract}
The registration of fiduciary security is regulated in the law number 42 in 1999 on Fiduciary Security and the implementation is regulated in Finance Ministerial Regulation Number 130 / PMK.010 / 2012. The registration of fiduciary security using a deed of fiduciary security must be done through a notary. However, in reality, it is found that the fiduciary deeds are made and registered by a notary that is outside the financing company's region. The purpose of this study is to determine and analyze the regulation and implementation of fiduciary security registration for financing companies according the Finance Ministerial Regulation Number 130 / PMK.010 / 2012. The method used on this research is an empirical juridical approach. Financing Companies are required to register fiduciary security at the Ministry of Law and Human Rights no later than 30 (thirty) days from the date of the consumer financing agreement. The registration of fiduciary security is done for upgrading public understanding and financial business actors to create public order. Fiduciary law needs to be understood more than just an instrument for registering vehicles security's, but to provide legal protection for society and financing companies for a certainty of execution to a default. Based on the author's description, it is necessary to register fiduciary security to provide protection, justice and legal certainty
\end{abstract}

Keywords: Fiduciary Security; Financing Institution; vehicle

\section{Introduction}

Fiduciary security has been used in Indonesia since the Dutch colonial era which was born from jurisprudence, apart from the imposition of being simple, easy, and fast, also the fiduciary can still control and use the pledged object so that it does not interfere with the economic activities of the fiduciary as a borrower / guarantor. Based on Article 1 of Law Number 42 of 1999 concerning Fiduciary Security. What is meant by Fiduciary Security is the right to movable objects, both tangible and intangible and immovable objects, especially buildings that cannot be encumbered with mortgage rights as referred to in Law Number 4 of 1996 concerning Mortgage Rights which remain under the control of the Fiduciary. as collateral for the redemption of certain money, which gives the Fiduciary priority over other creditors.

The enactment of Law Number 42 of 1999 concerning Fiduciary Security on September 30,1999 has provided a strong basis for fiduciary security agencies which have been based on jurisprudence in their considerations which state that the enormous and increasing need for the 
business world for the availability of funds is necessary. balanced with the existence of clear and complete legal provisions governing guarantee institutions. Fiduciary as a guarantee institution has long been known in Roman society which originally grew up and lived in customary law. In addition to developing in financing for the purchase of capital goods such as machinery, fiduciary also develops for consumer financing, such as financing the purchase of motor vehicles. This causes the automotive industry to develop rapidly along with the growth of the financial industry, particularly in terms of financing the purchase of motor vehicles facilitated by multi-finance companies or leasing using fiduciary guarantees.

The Ministry of Finance issued Regulation Number 130 / PMK.010 / 2012 concerning Fiduciary Security Registration for Financing Companies Conducting Consumer Financing for Motorized Vehicles with Fiduciary Guarantee Imposition. The issuance of Regulation of the Minister of Finance Number 130 / PMK.010 / 2012, the fiduciary guarantee must have been registered at the fiduciary registration office no later than 30 (thirty) calendar days, starting from the date of the consumer financing agreement. However, in reality, the problems that consumers often face in the practice of financing business activities, one of which is the lack of consumer understanding of how to regulate and implement the registration of fiduciary insurance. This can cause consumers themselves to experience losses because these weaknesses can be exploited by other parties. In reality, there are financial institutions that do not require fiduciary registration. This is very much felt in practice as a weakness and weakness for fiduciary legal institutions, because in addition to creating legal uncertainty, the absence of the Fiduciary Guarantee registration obligation causes the fiduciary guarantee to not fulfill the element of publicity, making it difficult to control.

The main issues that will be the main focus of attention will be discussed in this paper, namely, how to Regulate the Registration of Fiduciary Guarantee for Financing Companies based on the Minister of Finance Regulation Number 130 / PMK.010 / 2012 and How to Implement Fiduciary Security Registration for consumer financing for motorized vehicles with the imposition of Fiduciary Security. Social phenomena that currently appear are shown by negative behaviors and symptoms that indicate the erosion of the character of a nation. This phenomenon can be seen in daily life at school and in the community that there are still many students who do deviant deeds. When viewed further, the degradation of the values and morals of Pancasila as the core of character formation has not only struck the younger generation, but has penetrated to community leaders, students, educators, political officials, even to the leaders of the nation and state.

\section{Method}

The research was conducted to analyze the problems of implementing fiduciary insurance registration on motorized vehicles by financing institutions in Kuningan district, therefore the research method used is a juridical empirical research method, with qualitative analysis approach. The research specification used in this research is descriptive-analytical research. As an empirical legal research, this research focuses on field studies in the form of interviews with stakeholders and is supported by legal materials in the form of legislation, journal literature and the internet. 


\section{Result and Discussion}

\subsection{Registration of Fiduciary Guarantee for Financing Companies}

The fiduciary security agency has undergone a fundamental change, especially after the Fiduciary Guarantee Law was enacted. The main change is regarding the fiduciary security registration obligation. Although this registration is very important, it still raises questions and doubts about the registration obligation. This difference of opinion among legal experts is still a problem. Some said that what was registered was the certificate of fiduciary security, others said that not only the deed that was registered but the object must also be registered. The juridical facts, when analyzed from the clause of the fiduciary security deed made by a notary, it is found that what is registered is the fiduciary security deed and fiduciary security objects.10 Registration of fiduciary security has juridical consequences as stated in Article 2 of the Fiduciary Guarantee Law that the owner of the collateral is the creditor. the fiduciary, even though the debtor granting the fiduciary control physically controls the object. The position of the fiduciary who previously became the owner changes to Bezier. This opinion implies that there is a juridical separation of guaranteed property rights and guaranteed property rights in real.

The Fiduciary Guarantee is regulated through Law Number 42 of 1999 concerning Fiduciary Security, with the enactment of the Fiduciary Guarantee Law, binding debt guarantees made through the Fiduciary Guarantee must comply with the provisions of the law. According to article 5 paragraph (1) of Law Number 42 concerning Fiduciary Security "Objects Load with Fiduciary Security is made with a notary deed in Indonesian and is a deed of Fiduciary Security". Article 6 of the Fiduciary Guarantee Law states that "The Fiduciary Guarantee Act as referred to in Article 5 at least contains:

a. Identity of the Fiduciary Giver and Recipient

b. Basic agreement data guaranteed by fiduciary.

c. Description of objects that are the object of the Fiduciary Guarantee

d. Guarantee Value; and

e. The value of objects that are the object of the Fiduciary Guarantee.

Registration of Fiduciary Security is regulated in Article 11 paragraph (1) of Law Number 42 concerning Fiduciary Security which guarantees that "Objects that are encumbered with Fiduciary Security must be registered". Regarding the registration of Fiduciary Security is also regulated in the Minister of Finance Regulation Number 130 / PMK.010 / 2012 of 2012 concerning Registration of Fiduciary Security for Companies Conducting Consumer Financing for Motorized Vehicles with Fiduciary Guarantee Imposition. This Regulation of the Minister of Finance mandates that "Financing Companies are required to register Fiduciary Security at the Fiduciary Registration Office no later than 30 (thirty) working days from the date of the consumer financing agreement.

The government issued a regulation regarding the Fiduciary Security Registration Procedure as mandated by the provisions of Article 5 paragraph (2) and Article 13 paragraph (4) of Law Number 42 of 1999 concerning Fiduciary Security. At first the government issued Government Regulation Number 86 of 2000 concerning Procedures for Fiduciary Security Registration and Fees for Making Fiduciary Security Deeds, hereinafter referred to as PP Number 86 of 2000. However, in the course of time, Government Regulation Number 86 of 2000 was deemed no longer in accordance with legal developments. and community needs, so there needs to be new rules or regulations that can meet community needs. Furthermore, since April 2015, the Government issued Government Regulation Number 21 of 2015 concerning 
Fiduciary Security Registration Procedures and Fiduciary Security Deed Making Fees, hereinafter referred to as Government Regulation Number 21 of 2015.

The Fiduciary Guarantee Certificate as referred to in Article 15 paragraph (1) is included the words "Demi Keadilan Berdasarkan Ketuhanan Yang Maha Esa". It is clear here that the execution of the Fiduciary Guarantee based on the executorial title is an object that is burdened with a Fiduciary Guarantee that must be registered in accordance with Article 11 paragraph (1) of Law Number 42 of 1999 concerning Fiduciary Security. Provisions for the abolition of Fiduciary Security are also regulated in Article 25 paragraph (1) of Law Number 42 concerning Fiduciary Security which states that "Fiduciary Security is canceled due to the following matters:

a. Write-off of Debt guaranteed by Fiduciary

b. Waiver of rights to the Fiduciary Guarantee by the Fiduciary; or

c. Destruction of objects that are objects of Fiduciary Security

According to Article 1 PMK No. 130 / PMK.010 / 2012, Financing Companies that carry out consumer financing for motorized vehicles with the imposition of a fiduciary guarantee are required to register the intended fiduciary security at the Fiduciary Registration Office, in accordance with the law regulating fiduciary security (article 1). The obligation to register fiduciary security also applies to Financing Companies that:

a. motor vehicle consumer financing based on sharia principles;

b. and / or consumer financing for motor vehicles whose financing comes from channeling or joint financing.

With the issuance of this regulation, all finance companies must register fiduciary for each of their financing transactions. Therefore, article 2 PMK No. 130 / PMK.010 / 2012, states that Financing Companies are required to register fiduciary guarantees at the Fiduciary Registration Office no later than 30 (thirty) calendar days from the date of the consumer financing agreement. Minister of Finance Regulation No. 130 / PMK.010 / 2012 aims to ensure legal certainty for interested parties. Given that Law No.42 of 1999 contains many weaknesses, among others:

a. The time period for registering a fiduciary deed is not regulated.

b. It is prone to re-fiduciary and potential conflict because there is no registration period.

c. There are no strict sanctions against the binding of fiduciary guarantees carried out underhand.

d. There are no strict sanctions against the use of "selling power" which is clearly contrary to the methods of execution in accordance with Law No.42 of 1999 so that it has the potential to not provide a sense of justice for the debtor.

e. The rampant use of the power of attorney under-hand guarantees the potential for conflict also considering the validity of the signature in the power of attorney, unless legalized by a notary or a notarial power of attorney is made.

f. The Fiduciary Guarantee Registration Office has not been opened to remote areas of Indonesia, because most of the consumers of finance companies live in remote areas.

g. There is no uniformity in the use of the Data Base in the Registration Office.

However, the existence of Regulation of the Minister of Finance of the Republic of Indonesia No. 130 / PMK.010 / 2012 has had a positive impact on financing companies to support good corporate governance and ensure a sense of justice, benefit, legal certainty in the world of law. and the business world by regulating the following matters:

a. Emphasizing the provisions obliged to register fiduciary security at the Fiduciary Registration Office.

b. Confirming the registration period is a step to ensure legal certainty. 
c. Suppress actions that are contrary to the sense of justice by regulating the procedure for withdrawing fiduciary items.

d. The application of firm witnesses to violations of these provisions is very necessary as a coercive measure as well as for the registration of objects of fiduciary security.

e. It gives more sense of justice because by registering the object of fiduciary security, if the debtor is in default, the method of execution will be pursued in accordance with Law No.42 of 1999 .

\subsection{Discussion}

3.2.1 Implementation of Fiduciary Security Registration by Imposing Fiduciary Security. Based on the results of an interview on Monday, June 8, 2020 with the Head of the Kuningan District Leasing Financing Agency (BFI Finance) Branch, Mr. Riko Efri Pratama Explaining that the implementation of fiduciary security registration at the BFI Finance office in Kuningan Regency is still quite problematic, companies find it difficult to register fiduciary guarantees within 30 days, because it requires Proof of Motor Vehicle Ownership (BPKB). The BPKB is usually issued a month to two months after the financing is made. The BFI office also uses a notary whose position is at the center. All fiduciary registrations are registered directly by the head office and only part of the financing institutions use their own regional notaries, but most financial institutions in Kuningan Regency have collaborated with the Notary Center.

This will have an impact on the legal protection of the financial institution. When one day there is a violation committed by a customer. Financial institutions will find it difficult to obtain legal evidence related to the decision issued by the Ministry of Law and Human Rights on fiduciary registration. In order to create an agreement that has been agreed upon, the parties bound by the agreement can implement the contents of the agreement as it should. If the implementation of the agreement in the agreement, then what is expected as the purpose and purpose of holding the agreement will be created well without any disadvantaged parties who can claim for the losses they suffered. Article 1365 of the Criminal Code states that "Every act that violates the law that brings loss to another person, realizing the person who by mistake published the loss, reimburses the loss".

Based on the Regulation of the Minister of Finance No. 130 / PMK.010 / 2012 Article 2 which reads: "Financing companies are required to register fiduciary security at the Fiduciary Security Registration Office no later than 30 (thirty) calendar days from the date of the consumer financing agreement" The callously clearly states. that the financing company as the creditor registers the fiduciary security, even though the physical burden is with the debtor. When observed in practice, each financing institution has additional types of agreements that apply to one another. Based on Article 12 paragraph (1) of the Fiduciary Law states that "Fiduciary Security Registration as referred to in Article 11 paragraph (1) is carried out at a Notary and registered at the Fiduciary Registration Office." Meanwhile, according to the Elucidation of Article 12 it is stated that "the Fiduciary Registration Office is a within the Ministry of Justice (currently the Ministry of Law and Human Rights) and not an independent institution or technical implementing unit.

The Fiduciary Registration Office was established for the first time in Jakarta and gradually as needed in Provincial Capitals throughout the territory of the Republic of Indonesia. The facts on the ground show that in the Fiduciary Guarantee registration, there are still obstacles in carrying out registration of its fiduciary security. Financing Companies do not use their municipal notaries and that makes it difficult for financing institutions to have a Fiduciary Guarantee Certificate, so that in the absence of a Fiduciary Guarantee Certificate, 
their respective rights cannot be protected, both the Fiduciary Giver / Unit Owner. This Fiduciary Guarantee Certificate has the same strength as a Court Decision and is protected by the Fiduciary Law.

The handling of registration using a central notary makes it difficult for Fiduciary registration to be carried out effectively and efficiently. It is not surprising that in the end the use of Fiduciary is also not optimal, the compliance of financial institutions to register Fiduciary guarantees is also low, it is not uncommon for creditors, even though they charge Fiduciary registration fees, only register when debtors have entered the uncooperative stage and are in arrears of payments. This is because finance companies that have been neglecting registration obligations are forced to register. The fiduciary certificate can be obtained by the BFI office after registration of the fiduciary guarantee. Actually, as a rule, the Fiduciary certificate must have been issued 14 working days from the date of registration.

However, in practice, because now all Financing Companies are required to register their fiduciary guarantee, in practice there is a "crash" or a pile of files. So that in practice, the Fiduciary Guarantee Certificate will only be issued after 1.5 months from the date of registration. In the agreement there is no imposition, the BFI company is still required to register for fiduciary security, the old Fiduciary Deed, can still be registered (not expired). But those who have not previously imposed a fiduciary guarantee must continue to make a followup, on the basis of the Fiduciary Guarantee Authority. If a BFI company violates its obligations, according to Article 4 PMK No.130 / PMK.010 / 2012 which reads: Financial company companies "that violate will be subject to administrative witnesses in stages, in the form of warnings, freezing of business activities and revocation of business licenses, warning witnesses are given in writing a maximum of 3 (three) consecutive validity periods of 60 (sixty) calendar days.

If it turns out that before the expiration of the warning period the BFI company has met the conditions, the warning sanction may be revoked. The company has complied with the provisions, the Minister of Finance can revoke the warning sanction while the third warning validity period ends and the Financing Company still does not comply with the provisions, the Minister of Finance may impose a sanction to freeze business activities. The sanction for freezing of business activities is given in writing to the Financing Company, which is valid for a period of 30 (thirty) calendar days from the issuance of the witness letter to the freezing of business activities. Likewise, with the witness of business suspension, before the termination of the period of freezing of business activities of the Financing Company has complied with the provisions, the Minister of Finance shall revoke the sanction of freezing business activities and if until the end of the period of freezing of business activities as referred to the Financing Company does not comply with the provisions of the Minister of Finance to revoke the business license. The Financing Company concerned.

\section{Conclusion}

Regulations regarding Law Number 42 concerning Fiduciary Security, Minister of Finance Regulation No. 130 / PMK.010 / 2012 concerning Registration of Fiduciary Guarantees for Financing Companies Conducting Consumer Financing for Motor Vehicles with Fiduciary Charges with the issuance of this regulation, all finance companies must register fiduciary for each of their financing transactions. Therefore, article 2 PMK No. 130 / PMK.010 / 2012, states that Financing Companies are required to register fiduciary guarantees with the Ministry 
of Law and Human Rights no later than 30 (thirty) calendar days from the date of the consumer financing agreement. Registration of Fiduciary guarantees according to the Law and Regulation of the Minister of Finance Number 130 / PMK.010 / 2012 in order to increase public understanding and financing business actors in the context of realizing public order and legal certainty.

The community should better understand all the applicable regulations. Once again, the potential of Fiduciary needs to be understood as more than just an instrument for registering motor vehicle guarantees, but as a tool to support access to funding in a comprehensive manner. Financing Institutions still have obstacles in carrying out registration of their fiduciary guarantees, Financing Companies who not use their regional notaries and that makes it difficult for financing institutions to have Fiduciary Guarantee Certificates, so that in the absence of a Fiduciary Guarantee Certificate, their respective rights cannot be protected, either Giver of Fiduciary / Unit Owner. This Fiduciary Guarantee Certificate has the same strength as a Court Decision and is protected by the Fiduciary Law.

\section{References}

[1] Anita Kamilah, Keabsahan Sertifikat Jaminan Fidusia atas Barang Milik Pihak Ketiga yang dijaminkan Secara Melawan Hukum, Jurnal Dinamika, Volume 1, March 2016, p 3

[2] Andreas Albertus \& Andi Prajinto, Fiduciary Law, (Malang: Selaras Malang, 2010). p 45

[3] DY Witanto, Fiduciary Guarantee Law in Consumer Financing Agreement. Mandaraju , Bandung, 2015) p 32

[4] Gios Adhiyaksa. “Penerapan Asas Perlindungan Yang Seimbang Menurut Kuhperdata Dalam Pelaksanaan Perjanjian Kerja Untuk Waktu Tertentu Dihubungkan Dengan Undang-Undang Nomor 13 Tahun 2003 Tentang Ketenagakerjaan”. UNIFIKASI: Jurnal Ilmu Hukum. 3 (2). 2016. 78

[5] Khifni Kafa Rufaida dan Rian Sacipto, Tinjauan Hukum Terhadap Eksekusi Objek Jaminan Fidusia Tanpa Titel Eksekutorial yang Sah, Jurnal Refleksi Hukum, Volume 4 Nomor 1, Oktober 2019, p 21-40

[6] Munir Fuady, "Fiduciary Guarantee", (Bandung: Aditya Bakti, 2003), p. 63.

[7] Nurwidiatmo, 2011, Compilation of Legal Affairs on Leasing, (Jakarta: BPHN), p. 3

[8] Paparang Fatma, Journal of LPPM for the field Ekososbudkum, Volume 1 Number 2 of 2014 Implementation of Fiduciary Guarantee in Providing Credit in Indonesia, Faculty of Law, Sam Ratulangi University Manado. p 9

[9] Prihati Yuniarlin, "Penerapan Unsur-Unsur Perbuatan Melawan Hukum Terhadap Kreditur Yang Tidak Mendaftarkan Jaminan Fiducia", Jurnal Media Hukum, Volume 19, No. 1, Juni 2012, p. 2.

[10] Sri Ahyani Journal of Legal Insights, Vol. 24 No. February 1, 2011 legal protection for creditors through a fiduciary guarantee agreement. p 6

[11] Yudhistira, Eko, registration of fiduciary security, the obstacles are seen from the legal system aspects of the scientific journal of the law faculty of the University of North Sumatra, 2006, p 5

[12] Law Number 42 of 1999 concerning Fiduciary Security.

[13] Regulation of the Minister of Finance Number 130 / PMK.010 / 2012 concerning Fiduciary Security Registration which carries out consumer financing for motor vehicles with the imposition of a Fiduciary Guarantee 